\title{
Dual culture of the oomycete Lagenisma coscinodisci Drebes and Coscinodiscus diatoms as a model for plankton/parasite interactions
}

Anthony Buaya ${ }^{1,2}$, Alexandra Kraberg ${ }^{3,4}$ and Marco Thines ${ }^{1,2,5^{*}}$ (1)

\begin{abstract}
Diatoms are thought to provide about $40 \%$ of total global photosynthesis and diatoms of the genus Coscinodiscus are an important, sometimes dominant, cosmopolitan component of the marine diatom community. The oomycete parasitoid Lagenisma coscinodisci is widespread in the northern hemisphere on its hosts in the genus Coscinodiscus. Because of its potential ecological importance, it would be a suitable pathogen model to investigate plankton/parasite interactions, but the species cannot be cultivated on media without its host, so far. Thus, it was the aim of this study to explore the potential of dual culture of host and pathogen in the laboratory and to optimise cultivation to ensure a long-term cultivation of the pathogen. Here, we report successful cultivation of a single spore strain of $L$. coscinodisci (IsLA), on several Coscinodiscus species and strains, as well as the establishment of a cultivation routine with Coscinodiscus granii (CGS1 and CG36), which enabled us to maintain the single spore strain for more than 3 years in $6 \mathrm{~cm}$ Petri dishes and $10 \mathrm{ml}$ tissue culture flasks. This opens up the opportunity to study the processes and mechanism in plankton/parasitoid interactions under controlled conditions.
\end{abstract}

Keywords: Centric diatom, Coscinodiscus concinnus, C. granii, C. radiatus, C. wailesii, Cultivation, Laboratory, Oomycota, Pathosystem

\section{Introduction}

Oomycetes are fungal-like eukaryotes belonging to the Kingdom Straminipila, which also includes diatoms and brown seaweeds [1]. Oomycetes are present worldwide in terrestrial and marine ecosystems, where they act as saprotrophs and parasites of various eukaryotic groups [1-3]. Most of the more than 1000 known oomycete species are obligate parasites of flowering plants [2, 4], but many are also known as facultative animal pathogens [57] or saprotrophs in the limnic or marine environment [8-11]. More than $90 \%$ of the known oomycete species are in two orders, the Peronosporales in the sense of Hulvey et al. [8] and the Saprolegniales [1]. While these groups are characterised by the formation of sporangia

\footnotetext{
*Correspondence: m.thines@thines-lab.eu

${ }^{1}$ Department of Biological Sciences, Institute of Ecology, Diversity and Evolution, Goethe University Frankfurt am Main, Max-von-Laue-Str. 9, 60439 Frankfurt am Main, Germany

Full list of author information is available at the end of the article
}

that are delimited from the vegetative thallus, there are many species mostly in early-diverging oomycete lineages, which have holocarpic thalli. This means that the entire thallus is converted into a sporangium upon maturity [12-18]. Many of these species are parasitoids, and kill their hosts during colonisation [19-23]. Lagenisma coscinodisci is one of these parasitoids $[15,20,24]$ and is characterised by forming a branched thallus with stout hyphae in hosts of the large centric diatom genus Coscinodiscus. These hyphae later develop into sporangia in which hundreds to thousands of zoospores form to infect new hosts cells after release. The life cycle of the pathogen has been investigated in detail using transmission electron microscopy [25-29] and there is evidence for sexual reproduction by zoomeiospores instead of gametangia $[25,26]$. Lagenisma coscinodisci has been established in dual cultures previously $[24,30]$ but these cultures are no longer available. As the interaction between Coscinodiscus diatoms and their parasite $L$. coscinodisci might 
provide a suitable system to investigate plankton/parasite interaction, this study aimed at establishing a dual culture of Lagenisma and its hosts, as well as to optimise this culture towards a standardised model system.

\section{Materials and methods}

Diatom samples were collected at Helgoland Roads [31] using plankton nets with $20 \mu \mathrm{m}$ mesh sizes in August 2016 and screened for the presence of Lagenisma as described previously [20]. The parasite was found in both Coscinodiscus granii and C. wailesii. For establishing diatom cultures, single diatom cells were picked from the plankton sample, transferred three times through autoclaved seawater, and subsequently placed in small culture flasks (Sarstedt, Hamburg, Germany) filled with $10 \mathrm{ml}$ of sterile seawater supplemented with nutrients and trace minerals to obtain a seawater $\mathrm{f} / 2$ medium [32]. Flasks were incubated horizontally at $14{ }^{\circ} \mathrm{C}$ with a diurnal rhythm of $14 \mathrm{~h}$ light and $10 \mathrm{~h}$ darkness. While single cell isolates of the host diatoms were established, $L$. coscinodisci was maintained on mixed diatom samples, cultivated like the single diatom species cultures, but in $9 \mathrm{~cm}$ Petri dishes (Sarstedt). After 3-5 days, single diatoms were taken from the individual diatom cultures and transferred three times through sterile seawater using a $100 \mu \mathrm{l}$ pipette (Brand, Wertheim, Germany) and $200 \mu \mathrm{l}$ pipette tips (Sarstedt, Hamburg, Germany). This process was repeated until no other organisms apart from the potential diatom hosts could be observed. This way, pure cultures of C. concinnus, C. granii, C. radiatus, and $C$. wailesii were obtained. Subsequently, single diatoms from the corresponding species with a single thallus (i.e. derived from the infection by a single zoospore) of $L$. coscinodisci were picked from the mixed diatom sample, transferred three times through sterile seawater using a micropipette, and added to the corresponding single diatom host lines that had been allowed to multiply to at least 50 cells before infection. After pathogen thalli became apparent, diatoms with a single thallus were again transferred to an uninfected batch of the host. Subsequently, the transfer of infected cells to a new host was done every 7-14 days, and the cultivation was shifted to $6 \mathrm{~cm}$ Petri dishes (Sarstedt) instead of the cultivation flasks due to an easier handling and the lower costs associated with Petri dishes. After repeated cycles of infection for about 3 months the diatom/pathogen combination with the most steady infection rate was chosen for longterm cultivation as described above. Microscopy was performed as described previously [22] using an inverted microscope (AE30, Motic, Hong-Kong, China) for regular checks and subcultivation and a Zeiss Imager2 (Carl Zeiss, Jena, Germany) for microscopic images. For continuous supply of the host, CGS1 and CG36 were grown in $6 \mathrm{~cm}$ Petri dishes, and about 10 cells were transferred to new Petri dishes with marine $f / 2$ medium every 2 weeks to maintain the diatom cultures. After 1 week of growth, 1-5 infected cells were added in triplicates to non-infected hosts, and triplicates of the hosts were maintained uninfected, in parallel. As the infection success of ISLA in the two diatom lineages used is very high, only very few cases occurred, in which a single Petri dish with hosts did not get infected, which in those cases were likely due to an injury of the pathogen thallus during transfer. While it seemed that duplicates with a transfer of 2-3 thalli would be sufficient to ensure a continuous culture, we continued working with triplicates, keeping old cultures until first signs of infection were seen in new ones, to account for unforeseen events. Cultures of $C$. granii host strains (CGS1, CG36), and the L. coscinodisci

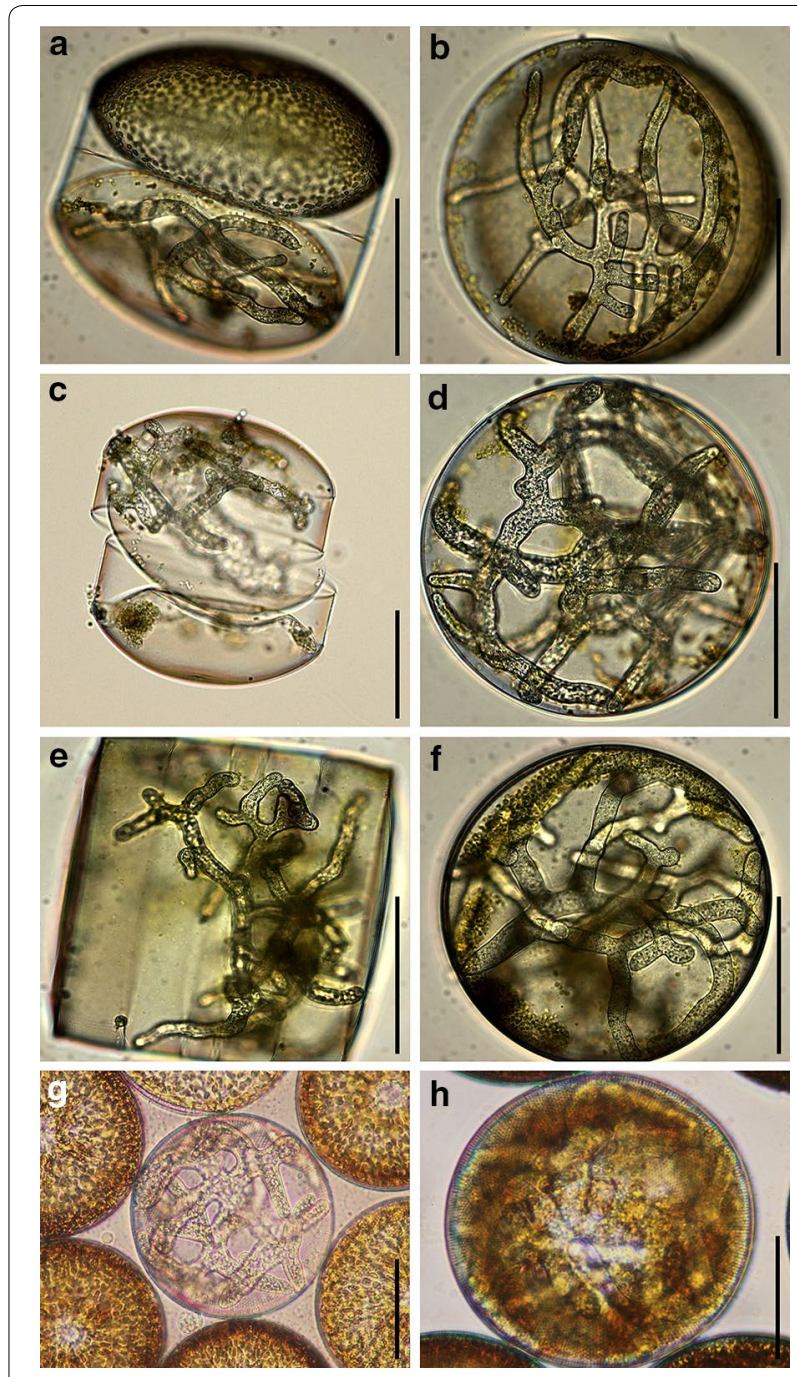

Fig. 1 Micrographs of Lagenisma coscinodisci in four diatom species. $\mathbf{a}, \mathbf{b}$ Coscinodiscus granii; $\mathbf{c}, \mathbf{d}$ C. concinnus; $\mathbf{e}, \mathbf{f} C$. wailesii; $\mathbf{g}, \mathbf{h} C$. radiatus. Scale bars equal $100 \mu \mathrm{m}$ in all pictures 
strain IsLA ( ${ }^{\text {st }}$ strain of Lagenisma) were deposited in the culture collection of the Thines laboratory and are available upon request to interested researchers. Unfortunately, no culture collection contacted felt able to host the dual culture. Requests from culture collections are, thus, particularly welcome.

\section{Results}

Initially, 16 cell lines of four isolated Coscinodiscus species were established; Strain CC1, CC2, CC3 for C. concinnus, CGS1, CG36, CG1, CG2, CG3, CG4, CG5 for C. granii, CR1, CR2, CR3 for C. radiatus, and CW1, CW2, CW3 for C. wailesii. All four diatom species could be infected by $L$. coscinodisci (Fig. 1 ), but infections were most reliably achieved in C. granii, which was therefore used as the sole host for further optimisation of the cultivation. Strains of the other diatom species were only kept to explore the effect of long-term cultivation. After about 1 year of cultivation, $C$. wailesii cultures had developed into cell sizes often less than $50 \mu \mathrm{m}$ and frustules became abnormally shaped and increasingly fragile. One of the cultures reverted back into normal-sized diatoms after auxospore formation, but the resulting strain was resistant to the strain that could previously infect this diatom species, but was kept on C. granii, when the C. wailesii cultures lost viability. Similarly, C. radiatus cultures declined after about one and a half years of continuous cultivation, and also C. concinnus could not be cultured long term. However, C. granii cultures remained stable over more than 2 years. After that period of time, they also grew to sizes below $50 \mu \mathrm{m}$, but several strains reverted into normally sized cells after auxospore formation. One strain of $L$. coscinodisci that very reliably infected C. granii strains, named IsLA, has (by the submission of this manuscript) been cultivated continuously for more than 3 years. Its lifecycle is shown in Fig. 2. IsLA is infective to C. concinnus, $C$. granii, and $C$. radiatus. Its speed of infection varied in different strains of C. granii. While in CGS1, the strain led to an infection peak at 6-7 days, with the majority of the diatoms infected, the peak of the infection was between 13 and 14 days in CG36 (Fig. 3). Because continued culture in CS36 thus necessitates transfer to a new host only every 2 weeks, it was chosen as the primary host for continued cultivation of IsLA.

\section{Discussion}

Diatoms account for about $40 \%$ of the global photosynthesis, most of which takes place in the open sea where centric diatoms often dominate. However, similar to the blooms of the well-studied coccolithophorid Emiliania
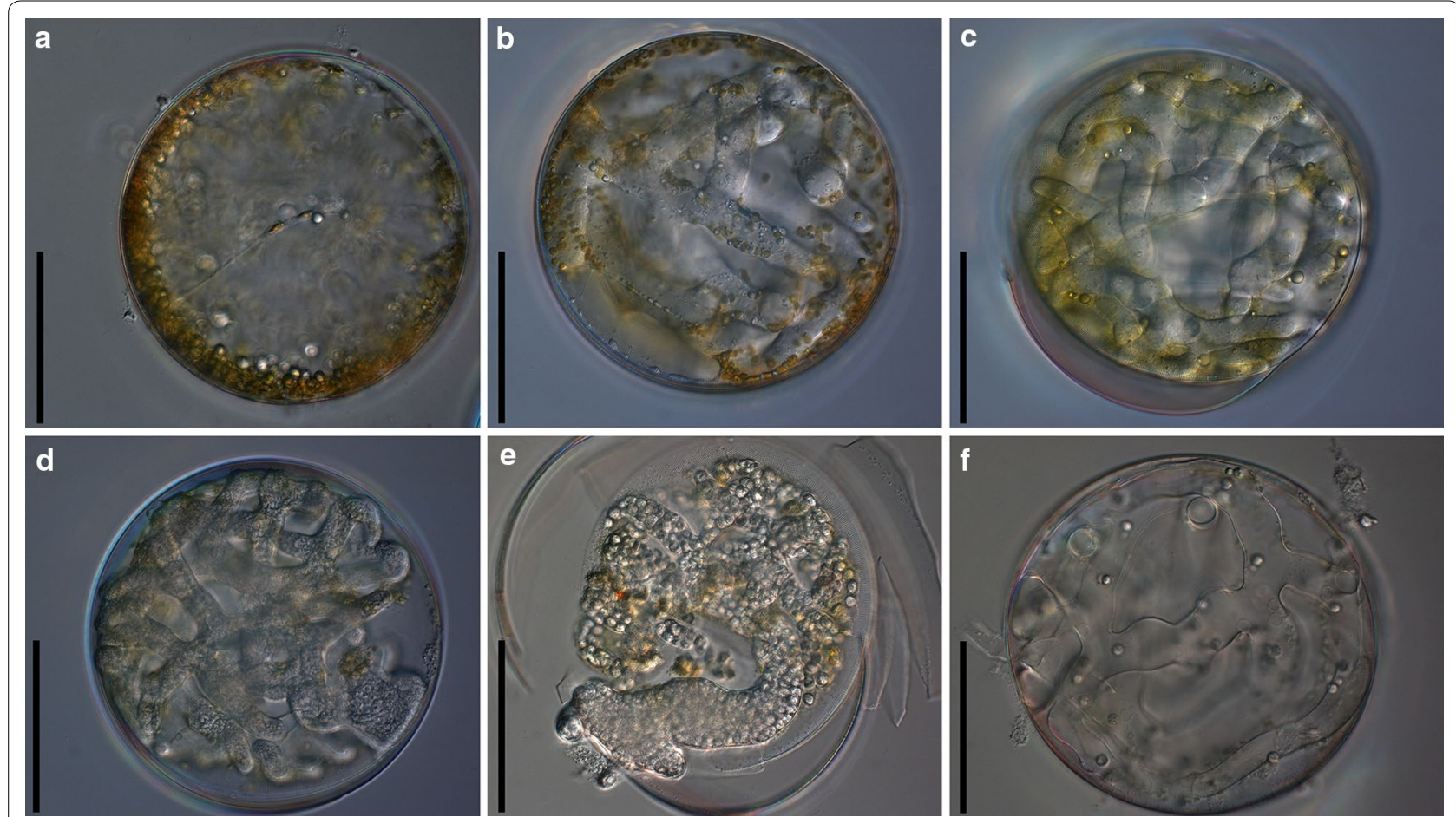

Fig. 2 DIC Micrographs of different infection stages of the Lagenisma coscinodisci strain IsLA in Coscinodiscus granii. a spore attachment and penetration; $\mathbf{b}$ growth phase; $\mathbf{c}$ early maturation phase; $\mathbf{d}$ intermediate maturation phase; $\mathbf{e}$ end of maturation phase, zoospore formation; $\mathbf{f}$ empty thallus after zoospore release. Scale bars equal $100 \mu \mathrm{m}$ in all pictures 
huxleyi [33], blooms often end abruptly. Members of the chytridiomycetes and oomycetes have been identified as important parasitoids of diatoms [34-36] and have been suggested as candidates for regulating diatom blooms that have previously been overlooked [37, 38]. Thus, it seems useful to establish laboratory model systems for investigating the interaction between diatoms and parasitoids for gaining insights into the processes and mechanisms in the infection process. Previously, apart from the Lagenisma/Coscinodiscus co-culture [30] dual culture of Coscinodiscus spp. and the nanoflagellate Pirsonia diadema had been achieved and proven useful for some basic insights into the interaction of diatoms and parasitoids, in particular host range [39] and the



b

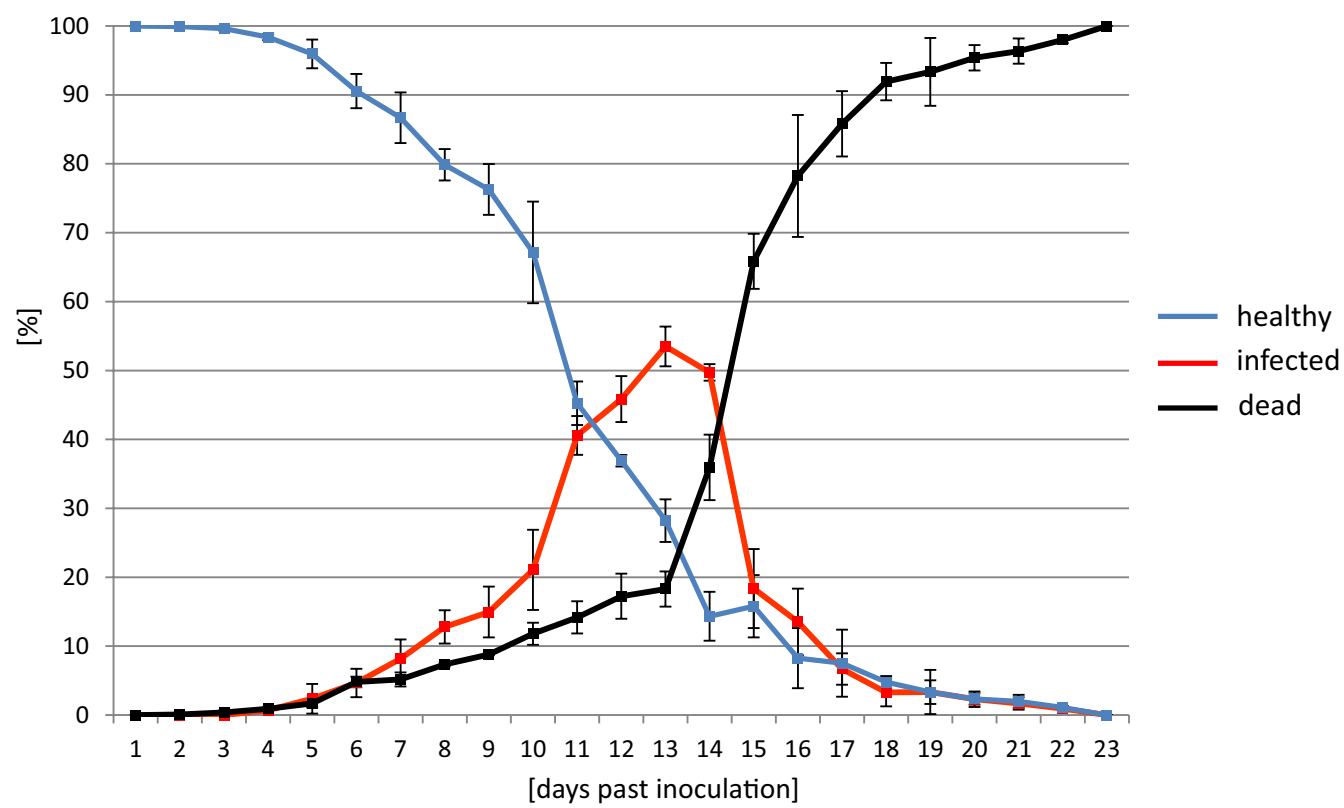

Fig. 3 Time course of infection of the Lagenisma coscinodisci strain IsLA in the two Coscinodiscus granii host lineages CG36 (a) and CGS1 (b). Error bars designate standard deviation from three replicates 
influence of abiotic factors on the outcome of infections [40]. However, the system had not been fully standardised and was discontinued. Similarly, the pathosystem of Asterionella and Rhizophydium planktonicum, was successfully cultivated over a longer period of time and has yielded insights into its host range [41] and the effect of abiotic factors on the infection process [42, 43]. However, also in this case, the culture was discontinued after some time. Therefore, a Lagenisma/Coscinodiscus pathosystem was re-established and optimised in this study. The strain IsLA, which can be obtained from the authors upon request, has been found to be particularly suited for this, as it remained stable in co-cultures with $C$. granii for 3 years. The virulence of IsLA varied in different diatom strains. While it reached the highest infection rate in CGS1 already after about a week, this took twice as long in CG36, suggesting the presence of quantitative resistance. In the present study, it could not be demonstrated that qualitative resistance to Lagenisma also existed in $C$. granii. But, as it was observed that susceptible lineages of C. wailesii became resistant after regeneration through auxospore formation, qualitative resistance might not be rare. Even though it is unclear, what the basis for resistance might be, it seems plausible that a gene-for gene interaction, similar to the situation in flowering plants, is responsible for this phenomenon. Apoptosis upon recognition in unicellular organisms prevents the spread of the pathogen. However, also the host individual with the particular genotype leading to apoptosis will die. But other, non-resistant individuals potentially profit from the sacrifice [44]. Thus, the Lagenisma/Coscinodiscus pathosystem might be an interesting one to elucidate mechanisms and evolutionary trajectories in the resistance development in unicellular organisms, as well as to study group selection of traits that are potentially fatal for individuals.

\section{Authors' contributions}

MT conceived the study, $A B$ and MT carried out initial cultivation experiments, $A B$ carried out all optimisation and long-term cultivation experiments, $A B$ and MT analysed the data, MT wrote the manuscript, with contributions from $A B$ and AK. All authors read and approved the final manuscript.

\section{Author details}

${ }^{1}$ Department of Biological Sciences, Institute of Ecology, Diversity and Evolution, Goethe University Frankfurt am Main, Max-von-Laue-Str. 9, 60439 Frankfurt am Main, Germany. ${ }^{2}$ Senckenberg Biodiversity and Climate Research Centre (BiK-F), Senckenberg Gesellschaft für Naturkunde, Senckenberganlage 25, 60325 Frankfurt am Main, Germany. ${ }^{3}$ Alfred Wegener Institute, Helmholtz Centre for Polar and Marine Research (AWI), Kurpromenade 201, 27498 Helgoland, Germany. ${ }^{4}$ Alfred Wegener Institute, Helmholtz Centre for Polar and Marine Research (AWI), Am Handelshafen 12, 27570 Bremerhaven, Germany. ${ }^{5}$ LOEWE Centre for Tranlational Biodiversity Genomics (TBG), Georg-Voigt-Str. 14-16, 60325 Frankfurt am Main, Germany.

\section{Acknowledgements}

The authors are deeply grateful to Dr. Drebes and Dr. Schnepf, for their pioneering work on Lagenisma, which prompted the current study. We also thank Silvia Peters for support during the lab work on Helgoland and the guest scientist team for their advice and help with logistics.

\section{Competing interests}

The authors declare that they have no competing interests.

\section{Availability of data and materials}

All data generated or analyzed during this study are included in this published article. The Coscinodiscus granii (CG36, CGS1) cell lines and the pathogen strain IsLA used in this study are available from the corresponding author upon request.

\section{Consent for publication \\ Not applicable.}

Ethics approval and consent to participate

Not applicable.

\section{Funding}

Funding by KAAD for a PhD fellowship to $A B$ and by the LOEWE initiative of the government of Hessen, in the framework of the Centre of Translational Biodiversity Genomics (TBG) for MT is gratefully acknowledged.

\section{Publisher's Note}

Springer Nature remains neutral with regard to jurisdictional claims in published maps and institutional affiliations.

Received: 31 January 2019 Accepted: 2 April 2019

Published online: 16 April 2019

\section{References}

1. Dick MW. Straminipilous fungi. Dordrecht: Kluwer Academic Publishers; 2001

2. Thines M. Phylogeny and evolution of plant pathogenic oomycetes-a global overview. Eur J PI Pathol. 2014;138(3):431-47.

3. Beakes GW, Thines M. Hyphochytriomycota and oomycota. In: Archibald JM, Simpson AGB, Slamovits CH, editors. Handbook of the protists. Heidelberg: Springer; 2017. p. 435-505.

4. Thines M, Choi Y-J. Evolution, diversity, and taxonomy of the Peronosporaceae, with focus on the genus Peronospora. Phytopathology. 2016;106(1):6-18.

5. Schurko AM, Mendoza L, Lévesque CA, Désaulniers NL, de Cock A, Klassen GR. A molecular phylogeny of Pythium insidiosum. Mycol Res. 2004;107(5):537-44.

6. van West P. Saprolegnia parasitica, an oomycete pathogen with a fishy appetite; new challenges for an old problem. Mycologist. 2006:20(3):99-104.

7. Krajaejun T, Khositnithikul R, Lerksuthirat T, Lowhnoo T, Rujirawat T, Petchthong $\mathrm{T}$, et al. Expressed sequence tags reveal genetic diversity and putative virulence factors of the pathogenic oomycete Pythium insidiosum. Fungal Biol. 2011;115(7):683-96.

8. Hulvey J, Telle S, Nigrelli L, Lamour K, Thines M. Salisapiliaceae—a new family of oomycetes from marsh grass litter of southeastern North America. Persoonia. 2010:25:109-16.

9. Marano AV, Jesus AL, de Souza Jl, Jeronimo GH, Gonclaves DR, Boro $M C$, et al. Ecological roles of saprotrophic Peronosporales (Oomycetes, Straminipila) in natural environments. Fungal Ecol. 2016;19:77-88.

10. Bennett RM, de Cock AWAM, Lévesque CA, Thines M. Calycofera gen. nov., an estuarine sister taxon to Phytopythium, Peronosporaceae. Mycol Prog. 2017;16(10):947-54

11. Bennett RM, Devanadera MK, Dedeles GR, Thines M. A revision of Salispina, its placement in a new family, Salispinaceae (Rhipidiales), and description of a fourth species, S. hoi sp. nov. IMA Fungus. 2018;9(2):259-69.

12. Karling JS. The simple holocarpic biflagellate Phycomycetes. New York: Karling JS; 1942.

13. Karling JS. Predominantly holocarpic and eucarpic simple biflagellate phycomycetes. Vaduz: J Cramer; 1981.

14. Sparrow FK. Aquatic phycomycetes. 2nd revised ed. Ann Arbor: University of Michigan Press; 1960 
15. Drebes G. Lagenisma coscinodisci gen. nov. sp. nov., ein Verterer der Lagenidiales in der marinen Diatomee Coscinodiscus. Veröff Inst Meeresforsch Bremerhaven. 1968;3:67-70.

16. Sekimoto S, Beakes GW, Gachon CMM, Müller DG, Küpper FC, Honda D. The development, ultrastructural cytology, and molecular phylogeny of the basal oomycete Eurychasma dicksonii, infecting the filamentous phaeophyte algae Ectocarpus siliculosus and Pylaiella littoralis. Protist. 2008;159(2):299-318.

17. Sekimoto S, Kochkova TA, West JA, Beakes GW, Honda D. Olpidiopsis bostychiae: a new species endoparasitic oomycete that infects Bostrychia and other red algae. Phycologia. 2009;48(6):460-72.

18. Klochkova TA, Shin Y, Moon KH, Motomura T, Kim G. New species of unicellular obligate parasite, Olpidiopsis pyropiae sp. nov., that plagues Pyropia sea farms in Korea. J Appl Phycol. 2016;28(2):939-50.

19. Beakes GW, Glockling SL, Sekimoto S. The evolutionary phylogeny of the oomycete "fungi". Protoplasma. 2012;249(1):3-19.

20. Thines M, Nam B, Nigrelli L, Beakes G, Kraberg A. The diatom parasite Lagenisma coscinodisci (Lagenismatales, Oomycota) is an early diverging lineage of the Saprolegniomycetes. Mycol Prog. 2015;14:75.

21. Buaya AT, Ploch S, Hanic L, Nam B, Nigrelli L, Kraberg A, Thines M. Phylogeny of Miracula helgolandica gen. et sp. nov. and Olpidiopsis drebesii sp. nov., two basal oomycete parasitoids of marine diatoms, with notes on the taxonomy of Ectrogella-like species. Mycol Prog. 2017; 16(11-12):1041-50.

22. Buaya ATB, Thines M. Miracula moenusica, a new member of the holocarpic parasitoid genus from the invasive freshwater diatom Pleurosira laevis. FUSE. 2019:3:19-33.

23. Buaya ATB, Ploch S, Thines M. Rediscovery and phylogenetic placement of Olpidiopsis gillii (de Wildeman) Friedmann, a holocarpic oomycete parasitoid of freshwater diatoms. Mycoscience. 2019. https://doi. org/10.1016/j.myc.2019.01.002.

24. Schnepf E, Drebes G. Über die Entwicklung des marinen parasitischen Phycomyceten Lagenisma coscinodisci (Lagenidiales). Helgoländer wiss Meeresunters. 1977;29(3):291-301.

25. Schnepf E, Deichgräber G, Drebes G. Development and ultrastructure of the marine parasitic oomycete Lagenisma coscinodisci Drebes (Lagenidiales). Thallus, zoosporangium, mitosis and meiosis. Arch Microbiol. 1978;116(2):141-50

26. Schnepf E, Deichgräber G, Drebes G. Development and ultrastructure of the marine, parasitic oomcete, Lagenisma coscinodisci (Lagenidiales). Sexual reproduction. Can J Bot. 1978;56(11):1315-25.

27. Schnepf E, Deichgräber G, Drebes G. Development and ultrastructure of the marine, parasitic oomycete, Lagenisma coscinodisci Drebes (Lagenidiales). The infection. Arch Microbiol. 1978;116(2):133-9.

28. Schnepf E, Deichgräber G, Drebes G. Development and ultrastructure of the marine, parasitic Oomycete, Lagenisma coscinodisci Drebes (Lagenidiales). Formation of the primary zoospores and their release. Protoplasma. 1978;94(3-4):263-80.
29. Schnepf E, Deichgräber G, Drebes G. Development and ultrastructure of the marine, parasitic oomycete, Lagenisma coscinodisci (Lagenidiales): encystment of primary zoospores. Can J Bot. 1978;56:1309-14.

30. Chakravarty DK. Zum Kultuverhalten des marinen parasitischen Pilzes Lagenisma coscinodisci. Veröff Inst Meeresforsch Bremerhaven. 1969;11:309-12.

31. Wiltshire KH, Kraberg A, Bartsch I, Boersma M, Franke HD, Freund J, et al. Helgoland Roads: 45 years of change in the North Sea. Estuaries Coasts. 2010:33(2):295-310.

32. Guillard RR, Ryther JH. Studies of marine planktonic diatoms: I. Cyclotella nana Hustedt, and Detonula confervacea (Cleve) Gran. Can J Microbiol. 1962;8(2):229-39.

33. Bratbak G, Egge JK, Heldal M. Viral mortality of the marine alga Emiliania huxleyi (Haptophyceae) and termination of algal blooms. Marine Ecol Prog Ser. 1993;93(1-2):39-48.

34. Rasconi S, Jobard M, Sime-Ngando T. Parasitic fungi of phytoplankton: ecological roles and implications for microbial food webs. Aq Microb Ecol. 2011;62:123-37.

35. Gutiérrez MH, Jara AM, Pantoja S. Fungal parasites infect marine diatoms in the upwelling ecosystem of the Humboldt current system off central Chile. Environ Microbiol. 2016;18(5):1646-53.

36. Scholz B, Guillou L, Marano AV, Neuhauser S, Sullivan BK, Karsten U, et al. Zoosporic parasites infecting marine diatoms—a black box that needs to be opened. Fungal Ecol. 2016;19:59-76.

37. Frenken T, Velthuis M, de Senerpont Domis LN, Stephan S, Aben R, Kosten $S$, et al. Warming accelerates termination of a phytoplankton spring bloom by fungal parasites. Glob Change Biol. 2016;22:299-309.

38. Raghukumar C. Diversity and role of fungi in the marine ecosystem. In: Dighton J, White JF, editors. The fungal community: its organization and role in the ecosystem. New York: CRC Press; 2017. p. 207-24.

39. Kühn SF. Infection of Coscinodiscus spp. by the parasitoid nanoflagellate Pirsonia diadema: II. Selective infection behaviour for host species and individual host cells. J Plankton Res. 1998;20:443-54.

40. Kühn SF, Hofmann M. Infection of Coscinodiscus granii by the parasitoid nanoflagellate Pirsonia diadema: III. Effects of turbulence on the incidence of infection. J Plankton Res. 1999;21:2323-40.

41. Canter HM, Jaworksi GHM. The isolation, maintenance and host range studies of a chytrid Rhizophydium planktonicum Canter emend, parasitic on Asterionella formosa Hassall. Ann Bot. 1978;42:967-79.

42. Canter HM, Jawrowski GHM. The effect of light and darkness upon infection of Asterionella formosa Hassall by the chytrid Rhizophydium planktonicum Canter emend. Ann Bot. 1981;47:13-30.

43. Bruning K. Infection of the diatom Asterionella by a chytrid. I. Effects of light on reproduction and infectivity of the parasite. J Plankton Res. 1991;13:103-17.

44. Franklin DJ, Brussard CPD, Berges JA. What is the role and nature of programmed cell death in phytoplankton ecology? Europ J Phycol. 2006:41:1-14.

\footnotetext{
Ready to submit your research? Choose BMC and benefit from:

- fast, convenient online submission

- thorough peer review by experienced researchers in your field

- rapid publication on acceptance

- support for research data, including large and complex data types

- gold Open Access which fosters wider collaboration and increased citations

- maximum visibility for your research: over 100M website views per year
}

At BMC, research is always in progress.

Learn more biomedcentral.com/submissions 